\title{
The Influence of Gender and Machiavellianism on Tax Evasion (A Study on Accounting Students)
}

\author{
Herlina Helmy ${ }^{1, *}$, Sany Dwita ${ }^{2}$, Charoline Cheisviyanny ${ }^{3}$ \\ 1,2,3 Universitas Negeri Padang, Padang, Indonesia \\ "Corresponding author.Email: herlina.helmy@fe.unp.ac.id
}

\begin{abstract}
This study aims to examine the influence of gender and Machiavellianism on tax evasion. This research is a causative research focusing on the context of accounting students. The data for this study were collected by using electronic survey distributed to 151 accounting students at Faculty of Economics, Universitas Negeri Padang. Multiple regression was used to analyze the data. The findings of this study show that gender has significant influence on tax evasion among accounting students. In particular, men tend to demonstrate tax evasion than women. Furthermore, the finding shows Machiavellianism has no significant influence on tax evasion.
\end{abstract}

Keywords: Gender, Machiavellianism, tax evasion.

\section{INTRODUCTION}

This research investigates the ethical judgement in accounting students on tax evasion. The idea of this research begins on many scandals happen in Indonesia. Some research in tax evasion take on economics and financial perspective. That is because of economist are utilitarian [19]. However, there is another perspective on tax evasion, such as psychological perspective. In this research we choose gender and Machiavellianism as psychological intrinsic motivation on tax evasion.

Gender is a psychological factor that can influence a person to commit tax evasion [10]. In language gender can be interpreted as the visible difference between men and women in terms of values and behavior. According to the gender socialization theory, men and women have different roles and values, thus forming differences in interests, decisions and practices between men and women. Gender socialization theory states that men are twice as likely to engage in unethical behavior than women [25]. The literature also shows that women are considered more risk-adverse than men [14]. Women will be more careful and try to avoid long-term risks that are considered to be burdensome for themselves when making decisions [6]. Several studies found that women are more ethical than men [3] and Female taxpayers are proven to have high tax morale [11]. Therefore, women are considered to have a lower tendency to commit tax evasion.

Several studies examined ethical attitudes towards tax evasion based on gender. [18] conducted a survey in 82 countries to ask men's and women's views on the ethics of tax evasion. The results show most of women are more resistant to tax evasion and this is often significant. [18] suggest more research is needed, because the reasons for tax evasion in each country are different. Various studies have shown that women are more against tax evasion which means women more obey the tax rules than men.

Furthermore, we also examine Machiavellianism as an internal factor that affects tax evasion. Individuals with Machiavellian character show cold, cynical behavior, pragmatic mindset and tend to be immoral. This behavior is based on long-term planning strategies, agentic motivation or selfinterest orientation, for example in terms of power or money. This individual can be involved in fraud and exploitation [21].

[24] explains the individual personalities who have Machiavellianism influence the ethical behavior and tendency on ethical dilemmas. Previous research on the influence of Machiavellianism on ethical decision making was conducted by [13] and [28]. They found a negative relationship, when a person has a high Machiavellian, the lower the ethical decision. [27], explained that Machiavellian has a negative and significant effect on students' ethical perceptions. Based on this research, the result shows that someone who has a Machiavellian tends to commit unethical acts, in this case is tax evasion.

This study examined the behavior of tax evasion from the psychological and internal perspectives of taxpayers, but some previous study asses the behavior from an economic approach in contrast. Recent literature has assessed that the economic approach fails to provide in-depth insights into tax 
compliance behavior because it put a lot of emphasis on economic factors and ignores psychological approaches [2]. Psychologists and economists admit that the traditional research paradigm with an economic approach is incomplete [1]. Several studies have shown that taxpayers include non-economic considerations in decision making [9].

Then, the purpose of this research examined the influence of internal factors, namely gender and Machiavellianism on tax evasion behavior among accounting students. The reason for using students is because students are considered to be able to represent practitioners in terms of decision making ([17]. A research with student subjects is important because students, especially undergraduate students, will become business people who will carry out all their tax obligations in the future and will carry out ethical decisions regarding their tax obligations. This research is expected to contribute to the taxation literature on tax evasion behavior from the internal and psychological perspectives of taxpayers.

\section{LITERATURE REVIEW}

\subsection{Tax evasion}

Tax evasion refers to illegal and deliberate actions by individuals to reduce tax obligations [1]. Tax evasion is a violation of tax laws by reporting understatement of income or reporting income greater than it actually is (overstatement) and a more severe form of tax evasion is not reporting income at all [22].

\subsection{Gender}

Gender socialization theory states that men and women have different roles and values in individual roles, thus forming differences in interests, decisions and practices between men and women. Women are considered to emphasize more on harmonious interpersonal relationships, care, and do a good job. While men put more emphasis on competitive success and extrinsic rewards including financial rewards and status and ignoring relationships between individuals. The difference behaviour of men and women causes men to be more likely to behave unethically to achieve a goal than women.

Several studies have proven the influence of differences in the roles of men and women to shape differences in behaviour, interests and decisions. The presence of women in the company is considered to increase the value of the company. The corporate governance system emphasizes the role of female directors on company boards, because women are believed to be more effective in monitoring the process of making a balance between shareholders
[12]. [16] states that female CFOs are less involved in earnings management and more conservative in financial reporting than male CFOs. In terms of tax avoidance, [12] also found that the presence of women on the board of directors reduces corporate tax avoidance.

Men and women also have different attitudes and behaviours in taxation. In terms of tax compliance, women are found to be more compliant than men [5]. [7] and [20] has shown that women are significantly more obedient than men. Women were also found to be more resistant to tax evasion than men. Women also tend to judge tax evasion behaviour as unethical behaviour [18]. Based on the description, this study expects that men tend to commit tax evasion than women because men are found to be more concerned with money, tend to engage in unethical behaviour while women are found to be more obedient and opposed to tax evasion behaviour. Therefore, based on the explanation, the hypothesis can be stated:

H1: Men are more likely to commit tax evasion than women

\subsection{Machiavellian}

The Machiavellian personality is described as a personality that has less affection in personal relationships, ignores conventional morals, and shows low ideological commitment (Richmond 2001). Machiavellian personalities have a tendency to manipulate other people and very low respect for others.

[4] stated that individuals with high Machiavellian tend to lie more. Individuals with high Machiavellian will be more likely to commit unethical actions than individuals with low Machiavellian, the higher a person's Machiavellian behaviour, the lower his ethical perception. [27] said that the higher a person's Machiavellian behaviour will have a significant negative effect on students' ethical perceptions. The higher a person's Machiavellian, the lower his ethical perception.

Machiavellian has a negative relationship with ethical perceptions. That is, the higher a person's Machiavellian the lower the ethics they have, so they tend to commit unethical acts such as tax evasion. Based on the above conclusions, it shows that the higher a person's Machiavellian, the lower their ethical perception, which results in them tending to commit tax evasion. Based on the description, the hypothesized is:

$\mathrm{H} 2$ : Machiavellian has a significant positive effect on tax evasion behaviour 


\section{METHODS}

This research is a causative research with subjects of accounting students at the Faculty of Economics, State University of Padang. A total of 151 students participated in this study. The selected students are students who have attended and passed the taxation course. Students who have passed the taxation course are assumed to have adequate understanding and can represent taxpayers in this study. The data in this study were collected through an electronic survey. This study uses a research instrument by [15] to assess tax evasion behavior.

Gender is measured using a dummy with a symbol of 1 for men and 0 for women. Meanwhile, Machiavellian is measured using the Mach IV and the instrument consists of 20 question items. Then, the respondent is given a statement with a Likert scale which will contain a statement about the level of agree and disagree for each statement item, namely a score of 1 (strongly disagree) to 5 (strongly agree). The higher the score means the higher Machiavellian behavior of the respondent. The data collected were analyze by multiple regression analysis.

\section{RESULT}

A total of 151 responses were used for analysis in this study. Demographic statistics show that as many as 96 women $(63 \%)$ and 55 men $(37 \%)$. The F test results show a significance value of 0.001 , less than 0.05. The results of this study also show an Adjusted $\mathrm{R}$ Square value of 0.074 , which means that the research variable is able to explain $7.4 \%$ of the change in the value of the dependent variable, namely the behaviour of tax evasion. Meanwhile, the remaining $92.6 \%$ is explained by other variables not examined in this study. The analysis was then continued with hypothesis testing with the t test.

The first hypothesis formulated is gender has a significant influence on tax evasion behavior, men tend to commit tax evasion than women. The results of the regression analysis showed that the positive regression coefficient for gender was 1.363. These results indicate that gender has a positive effect on tax evasion behavior in accounting students (Y). That is, based on the respondent's answer to the case of tax evasion, it shows that female students tend to be more obedient, while male students tend to commit tax evasion. In addition, the results of the regression analysis showed a significant value, 0.001 which is less than 0.05. This means that gender has a significant influence on tax evasion behavior in accounting students. Thus, the first hypothesis is supported.
The results of this study were successful in showing that there was a significant effect of gender differences on tax evasion behavior, where male students were more likely to commit tax evasion. The results of this study are in line with some of the results of previous studies which state that women are more obedient than men $[7 ; 20]$. The results of this study are in line with the findings of [18] who conducted a survey in 82 countries, where the results showed that $63 \%$ of countries showed that women were significantly against the behavior of tax evasion. The results of this study are also in line with the gender socialization theory which states that men and women have different roles and values, which shape differences in interests, decisions and practices. The difference between men and women is due to the fact that men and women are dissociated differently. Men are considered more likely to engage in unethical behavior than women [25].

The second hypothesis formulated is the Machiavellian has a significant influence on tax evasion behavior. The outcomes of the regression analysis showed a negative coefficient value of 0.016 which indicates a negative influence between Machiavellian characteristics (X2) and tax evasion behavior (Y). This means that this supports the argument that the higher a person's Machiavellian behavior, the lower their ethics, so that they tend to commit unethical acts such as tax evasion. Furthermore, the results of regression analysis showed a significant value, namely 0.367 greater than 0.05 . The outcome of this research reveal that Machiavellian does not have a significant effect on tax evasion behavior. Thus, the second hypothesis is not supported.

The results of this study are in line with the results of [8] study which found that Machiavellianism had no effect on students' ethical perceptions of tax evasion behavior. This can happen because in addition to internal factors, respondents also consider external factors. This can also be caused because accounting students have obtained ethics courses so that they perceive tax evasion behavior as fraud.

\section{CONCLUSION}

The aim of this research was to empirically examine the effect of gender and Machiavellian on tax evasion behavior among accounting students. Data from this study were obtained through an electronic survey of 151 accounting students at the Faculty of Economics, Padang State University, who had attended and passed taxation courses. The data were analyzed using multiple linear regression analysis. 
The results of this study indicate that gender as an individual internal factor affects tax evasion behavior. Women were found to be more compliant while men were more likely to commit tax evasion. However, the results of this study did not find a significant effect between Machiavellianism and tax evasion behavior.

\section{REFERENCES}

[1] Alm, J. (2018). What motivates tax compliance. Journal Economics Surveys, 1-36.

[2] Aneyaw, B., Oppong, A., Abruguah, L. A., \& Ashalley, E. (2016). Informal sector tac compliance issues and the causality nexus between taxation and economic growth: Emperical evidence from Ghana. Moderen Economy, 1478-1497.

[3] Betz, M., O'Connell, L., \& M.Shepard, J. (2013). Gender Differences in Proclivity for Unethical Behavior. Springer Science Business Media, 427-432.

[4] Charismawati, C. (2011). Analisis Hubungan antara Love of Money dengan Persepsi Etika Mahasiswa Akuntansi. Jurnal Akuntansi, Universitas Diponegoro.

[5] Chau, G., \& Leung, P. (2009). A critical review of Fisher tax compliace model: A research synthesis. Journal of Accounting and Taxation, 034-040.

[6] Dewanta, M. A., \& Machmuddah, Z. (2019). Gender, Religiosity, Love of Money and Ethical Perception of Tax Evasion. Jurnal Dinamika Akuntansi dan Bisnis, 71-84.

[7] D'Attoma, J., Volintiru, C., \& Steinmo, S. (2017). Willing to share? Tax compliance and gender in Europe and America. Research and Politics, 1-10

[8] Farhan, M., Helmy, H., \& Afriyenti, M. (2019). Pengaruh Machiavellian dan Love of Money Terhadap Presepsi Etika Penggelapan Pajak dengan Religiusitas Sebagai Variabel Moderasi (Studi Empiris Pada Wajib Pajak Di Kota Padang) . Jurnal Eksplorasi Akuntansi , 470486.

[9] Farrar, J., Kaplan, S., \& Thorne, L. (2017). The Effect of Interactional Fairness and Detection on Taxpayers' Compliance Intentions. Journal Business Ethics.

[10] Fischer, C., Wartick, M., \& Mark, M. (1992). Detection Probability and Tax Payers
Compliance: A Review of Literature. Journal of Accounting Literature, Vol 11 pp 1-46.

[11] Hartmann, A., Mueller, M., \& Kirchler, E. (2019). Tax Compliance: Research Methods and Decision Processes. WU International Taxation Research Paper Series.

[12] Hoseini, M., Gerayli, M. S., \& Valiyan, H. (2018). Demographic characteristics of the board directors stucture and tax avoidance: Evidence from Tehran Stock Exchange. International Journal of Sosial Economics.

[13] Jiwo, Pranan. (2011). Analisis Faktor-Faktor Individual dalam Pengambilan Keputusan Etis oleh Konsultan Pajak di Kota Semarang. Semarang FEB Universitas Diponegoro.

[14] Kastlunger, B., Dressler, S., Kirchler, E., Mittone, L., \& Voracek, M. (2010). Sex Differences in tax compliance: Differentiating betwwen Demographic Sex, Gender-Role Orientation and Prenetal Masculinization (2D:4D). Journal of Economic Psychology, 542552.

[15] Lewis, A., Carrera, S., Cullis, J., \& Jones, P. (2009). Individual, cognitive and cultural differences in tax compliance: UK and Italy compared. Journal of Economic Psychology, 431-445.

[16] Liu, Y., Wei, Z., \& Xie, F. (2016). CFO gender and earnings management: Evidence from China. Review of Quantitative Finance and Accounting, 881-905.

[17] Liyanarachchi, G., \& Milne, M. (2005). Comparing the investment decisions of accounting practitioners and students: An empirical study on the adequancy of students surrogates. Accounting Forum, 121-135.

[18] McGee, R. (2014). Gender and The Ethics of Tax Evasion: An Emperical Study of 82 Countries. SSRN.

[19] Nasyaduk, Irina and McGee, Robert W. (2006). The Ethics Of Tax Evasion: An Empirical Study Of Business And Economics Student Opinion In Ukraine. Andreas School of Business Working Paper Series, Barry University, Miami Shores, FL 33161 USA.

[20] Puspitaningrum, R. R. (2018). Pengaruh Gender, Level Pendidikan, TIngkat Pendapatan dan Keragaman Etnis terhadap Perilaku Kepatuhan Wajib Pajak Orang Pribadi (Penerapan Theory of Planned Behavior). DSpace Reposotory Universitas Islam Indonesia. 
[21] Rahman, Abdul. (2013). Pengaruh Karakteristik Individu, Motivasi dan Budaya Kerja terhadap Kinerja Pegawai pada Badan Keluarga Berencana dan Pemberdayaan Perempuan Kabupaten Donggala. E-Jurnal Katalogis, ISSN: 2302-2019, Vol. 1, No. 2, hlm 77-86.

[22] Rantelangi, C., \& Majid, N. (2018). Factors that Influence the Tax Payers Perception on Tax Evasion. Advances in Economics Bussiness and Manajemen Research, 219-225.

[23] Richmond, Kelly Ann.(2001). "Ethical Reasoning, Machiavellian Behavior, and Gender: The Impact on Accounting Students Ethical Decision Making”. Disertasi, Blacksburg, Virginia.

[24] Richmond, Kelly. (2003). Machiavellianism And Accounting: An Analysis Of Ethicalbehavior Of Us Undergraduate Accounting Student And Accountants, Symposium On Ethich Research In Accounting, American Accounting Association.

[25] Tjondoro, E., Widuri, R., \& Manoy, S. B. (2019). Different Cities, Different Genders, Different Perception of Tax Evasion. 3rd International Conference on Economics, Education, Business and Accounting Volume (pp. 133-150). Bali: KnE Social Sciences.

[26] Torgler, B. (2002). Speaking to Theorists and Searching for Facts: Tax Morale and Tax Compliance in Experiments. Journal of Economics Surveys, 657-683.

[27] Toriq, I. A. (2015). Pengaruh Love Of Money Dan Machiavellian Terhadap Peesepsi Etis Mahasiswa Akuntansi (Studi Empiris Pada Mahasiswa Akuntansi UNY Angkatan 20132014). Skripsi Ekonomi Akuntansi Yogyakarta: Univesitas Negeri Yogyakarta.

[28] Yuliana. (2012). Analisis Pengaruh Persepsi Pentingnya Etika dan Tanggung Jawab Sosial, Sifat Machiavellian dan Keputusan Etis Terhadap Niat Berpartisispasi dalam Penghindaran Pajak (Studi Empiris Pada Konsultan Pajak di Semarang). Diponegoro Journal of Accounting. 